REVISTA DE DERECHO UNED, núm. 3, 2008

\title{
EL ACCESO DE LOS MEDIOS AUDIOVISUALES A LAS SALAS DE VISTAS EN LOS PROCESOS PENALES
}

\author{
JuAn Carlos Orenes RuIZ \\ Letrado del Consejo Audiovisual de Navarra
}

Resumen: Existe una estrecha relación entre la libertad de información y el principio de publicidad consagrado en el artículo 120.1 de la Constitución. Tras analizar su significado y las limitaciones que pueden imponerse al mismo, el artículo estudia la controvertida cuestión del acceso de los medios audiovisuales a los actos que se celebran en audiencia pública en los Tribunales de Justicia.

Los periodistas como intermediarios naturales entre la noticia y los ciudadanos tienen un derecho de acceso preferente a las vistas públicas. Las sentencias del Tribunal Constitucional 56 y 57 de 2004 han fijado el principio de libre acceso como la regla general, mientras que cualquier restricción tendrá un carácter excepcional, siendo precisa una resolución expresa al respecto. Esta doctrina ha tenido reflejo tanto en Reglamento 1/2005 del CGPJ como en la Instrucción 1/2005 de la FGE, no obstante, la práctica evidencia que su consolidación requerirá del transcurso de un periodo de tiempo suficiente para desterrar las tradicionales reservas que la presencia de los medios audiovisuales despiertan en un sector de la judicatura. El artículo considera imprescindible que el legislador establezca una mínima regulación de las diversas cuestiones que plantea el acceso de los medios audiovisuales. Estas normas dotarían de uniformidad a las decisiones que se adopten en esta materia evitando prácticas y usos diferenciados que van en detrimento de la necesaria seguridad jurídica.

Palabras clave: libertad de información, medios audiovisuales, principio de publicidad, salas de vistas, derecho de acceso preferente. 
Abstract: There is a close relationship between freedom of information and the principle of a public hearing under article 120.1 of the Constitution. After analyzing its meaning and its limitations, this article explores the controversial issue of the access of audiovisual media to the courtrooms.

Journalists as natural intermediaries between the news and citizens have a right to preferential access to public hearings. The sentences of the Constitutional Court 56 and 57/2004 has set the principle of free access as a general rule, while any limitation or restriction is exceptional and must have a specific resolution on the matter. This doctrine has been reflected immediately in Regulation 1/2005 of General Council of Judicial Power and in Instruction 1/2005 of State Public Prosecutor. However, experience shows that consolidation would require a sufficient period of time to eliminate the traditional cautions that the presence of the audiovisual media awaken in a sector of the judges. The article considers that it's necessary a law action that sets a minimum regulation framework about main issues arise from the audiovisual media access. These rules will provide uniformity decisions and thus avoid differentiated practices that harm the necessary legal certainty.

Key words: freedom of information, audiovisual media, principle of a public hearing, courtrooms, preferential access.

Sumario. 1. EL PRINCIPIO DE PUBLICIDAD. 2. RESTRICCIONES A LA PUBLICIDAD. LOS JUICIOS A PUERTA CERRADA. 3. EL ACCESO DE LOS MEDIOS DE COMUNICACIÓN. 4. EL ACCESO DE LOS MEDIOS AUDIOVISUALES. 4.1. Efectos que produce la presencia de los medios audiovisuales. 4.2. El acceso de los medios de comunicación en el derecho interno. 4.3. La doctrina establecida por el Tribunal Constitucional en las sentencias 56/2004 y 57/2004. 4.4. El Protocolo de Comunicación de la Justicia. 4.5. El papel del Ministerio Fiscal. 4.6. La difícil implantación de la doctrina del Tribunal Constitucional. BIBLIOGRAFÍA.

\section{EL PRINCIPIO DE PUBLICIDAD}

Una de las notas que caracteriza el ejercicio de la libertad de información sobre la actividad que se desarrolla ante los Tribunales de Justicia es la existencia de una doble cobertura constitucional. Por un lado, y como es obvio, se encuentra amparada por el reconocimiento 
constitucional expreso que se hace de este derecho en el artículo 20.1.d de la Constitución; por otro, y esto es lo significativo, la libertad informativa se encuentra estrechamente relacionada con el principio de publicidad que se recoge en el artículo 120 del referido texto, que establece que las actuaciones judiciales serán públicas, con las excepciones que prevean las leyes de procedimiento.

La vinculación entre la libertad de información y el principio de publicidad fue advertida, desde un primer momento, por la jurisprudencia constitucional al considerar que la publicidad procesal está inmediatamente ligada a posiciones subjetivas de los ciudadanos, que tienen la condición de derechos fundamentales: el derecho a un proceso público del artículo $\mathbf{2 4 . 2}$ de la Constitución y el derecho a recibir libremente información ${ }^{1}$. El derecho a un proceso público constituye una aportación fundamental del pensamiento ilustrado al derecho procesal ${ }^{2}$, la publicidad fue considerada por BENTHAM como «el alma de la justicia» y, modernamente, es una exigencia ineludible en los sistemas democráticos puesto que la publicidad permite que la actividad judicial pueda ser conocida por los ciudadanos y, por lo tanto, ser sometida al control y crítica de los mismos ${ }^{3}$.

Al hablar de publicidad nos estamos refiriendo a la publicidad en sentido propio, como publicidad absoluta, que supone la percepción de las actuaciones procesales por cualquier persona ajena al proceso, por terceros que no son parte en el mismo, en definitiva, por cualquier ciudadano. La publicidad externa está dotada, a su vez, de una doble dimensión, por un lado presenta una dimensión individual, que aparece contenida en el artículo 24.2 de la Constitución donde se reconoce el derecho a un proceso público; y por otro, una dimensión colectiva, a la que hace referencia el artículo 120 de la Constitución, y que aparece íntimamente conectada con la libertad de información contenida en el artículo 20, en cuanto la publicidad de las actuaciones procesales permite que la justicia sea sometida al control del público, sustentando la confianza de los ciudadanos en la Justicia ${ }^{4}$.

SSTC 30/1982 y $13 / 1985$.

2 LÓPEZ ORTEGA, J.J.: «La dimensión constitucional del principio de la publicidad de la justicia» en Justicia, información y opinión pública, Revista del Poder Judicial, n. ${ }^{\circ}$ especial XVII. CGPJ, Madrid, 1999, pp. 102 y 103.

3 ROXIN considera que la publicidad es el factor democrático central del proceso. ROXIN, C.: «El Proceso Penal y los medios de comunicación», en Revista del Poder Judicial, $n .^{\circ} 55$. CGPJ, Madrid, 1999.

${ }^{4}$ Junto a aquélla, existe una dimensión individual que afecta únicamente a las personas sujetas al proceso, de manera que el derecho al proceso público contenido en el artículo 24.2 del texto constitucional supone una garantía para el justiciable frente a una justicia secreta que escape a la fiscalización por parte de la opinión pública. 
En definitiva, la publicidad del proceso viene exigida por la necesidad de control por parte de la opinión pública de todos y cada uno de los poderes del Estado, exigencia propia de los sistemas democráticos y que aparece conectada con la consideración de la Administración de Justicia como un verdadero servicio público. Supone, además, para el justiciable una garantía individual, pues la posibilidad de fiscalización pública de la actuación de los tribunales le preserva frente a eventuales actuaciones judiciales arbitrarias, injustas o irrazonables $^{5}$. El Tribunal Constitucional ha destacado esta doble finalidad, que consiste por un lado en proteger a las partes de una justicia sustraída al control público, y por otro, en mantener la confianza de los ciudadanos, constituyendo en ambos sentidos tal principio «una de las bases del debido proceso y uno de los pilares del Estado de Derecho" ${ }^{6}$.

\section{RESTRICCIONES A LA PUBLICIDAD. LOS JUICIOS A PUERTA CERRADA}

En el proceso penal el principio de publicidad es aplicable en su verdadera dimensión, además de a la sentencia, al proceso en sentido estricto, es decir, al acto del juicio oral y así ha sido reconocido por el Tribunal Constitucional ${ }^{7}$. Recordemos que en la LECrim se establece, expresamente, el secreto externo de la fase sumarial al establecer, en su artículo 301.1 que: «Las diligencias del sumario serán secretas hasta que se abra el juicio oral, con las excepciones determinadas en la presente ley» 8 .

${ }^{5}$ Como indica el Protocolo de Comunicación de la Justicia, aprobado por la Comisión de Comunicación del CGPJ el 30 de junio de 2004, con el visto bueno del Pleno del CGPJ del día 7 de julio del mismo año: «El principio de publicidad de la Justicia constituye la garantía esencial del funcionamiento del Poder Judicial en una sociedad democrática como la nuestra, no sólo porque fortalece la confianza pública en la Justicia sino también porque fomenta la responsabilidad de los órganos de la Administración de Justicia».

- STC 96/1987, de 10 de junio, en su fundamento jurídico $2 .^{\circ}$

${ }^{7}$ La sentencia $176 / 1988$, en su fundamento jurídico $2 .^{\circ}$ indica que: «...el derecho al proceso público del artículo 24.2 de la Constitución, como garantía de los justiciables, sólo es de aplicación, además de a la sentencia, al proceso en sentido estricto, es decir, al juicio oral en el que se producen o reproducen las pruebas de cargo y descargo y se formulan las alegaciones y peticiones definitivas de la acusación y la defensa, pues únicamente referida a ese acto procesal tiene sentido la publicidad del proceso en su verdadero sentido de participación y control de la justicia por la comunidad».

${ }^{8}$ El Tribunal Constitucional se ha pronunciado sobre la constitucionalidad de una fase amparada por el secreto, refiriéndose a la misma al hablar de la "genérica constitucionalidad del secreto sumarial» en la STC 13/1985. 
La legislación procesal penal acoge expresamente la vigencia del principio de publicidad en la fase de juicio oral en los artículos 649.2. ${ }^{\circ}$ y $680.1 .^{\circ}$ de la LECrim; el primero de ellos establece que dictada la resolución por la que se declara abierto el acto del juicio oral, los actos del proceso serán públicos, el segundo señala que los debates del juicio oral serán públicos bajo pena de nulidad?

Dejando al margen las cuestiones relativas al secreto de la fase instructora, que genera una compleja problemática que merece ser analizada separadamente, la mayor limitación que puede sufrir el principio de publicidad durante la fase de juicio oral es la resolución por la que se acuerda la celebración del acto de la vista a puerta cerrada, que impide la asistencia al mismo de cualquier persona ajena al proceso.

A nivel internacional, tanto el artículo 6 del Convenio Europeo para la Protección de los Derechos Humanos y Libertades Fundamentales de $1950^{10}$ como el artículo 14 del Pacto Internacional de Derechos Civiles y Políticos de $1966^{11}$ se refieren a la posibilidad de restringir el acceso a las salas de justicia ${ }^{12}$. El propio texto constitucional advierte en el artículo 120.1 que el principio de publicidad es susceptible de sufrir limitaciones de acuerdo con lo que dispongan las

${ }^{9}$ Concretamente dispone el artículo 649 de la LECrim: “Cuando se mande abrir el juicio oral, se comunicará la causa al Fiscal, o al acusador privado si versa sobre delitos que no puedan ser perseguidos de oficio, para que en el término de cinco días califiquen por escrito los hechos. Dictada que sea esta resolución, serán públicos todos los actos del proceso». Por su parte el artículo 680.1 establece que: "Los debates del juicio oral serán públicos bajo pena de nulidad».

10 Que establece que: «...el acceso a la Sala de la Audiencia puede ser prohibido a la prensa y al público durante la totalidad o parte del proceso en interés de la moralidad, del orden público o de la seguridad nacional en una sociedad democrática, cuando los intereses de los menores o la protección de la vida privada de las partes en el proceso así lo exijan o en la medida considerada necesaria por el Tribunal, cuando en circunstancias especiales la publicidad pudiera ser perjudicial para los intereses de la justicia".

11 Que en términos muy similares señala que «la prensa y el público podrán ser excluidos de la totalidad o parte de los juicios por consideraciones de moral, orden público o seguridad nacional en una sociedad democrática, o cuando lo exija el interés de la vida privada de las partes o, en la medida estrictamente necesaria en opinión del tribunal, cuando por circunstancias especiales del asunto la publicidad pudiera perjudicar los intereses de la justicia».

12 La importancia de estos preceptos viene determinada por el propio texto constitucional, que en su artículo 10.2 establece que la interpretación de las normas relativas a los derechos fundamentales debe hacerse conforme a los tratados internacionales ratificados por España en materia de derechos fundamentales. En último término la celebración del juicio a puerta cerrada afecta al derecho fundamental a un proceso público. 
leyes de procedimiento. De este modo aparecen limitaciones al principio de publicidad en distintas leyes procesales; con carácter general, la LOPJ así lo admite en su artículo 232.2 por razones de orden público y de protección de los derechos y libertades ${ }^{13}$. Por su parte, la LECrim se refiere concretamente a la posibilidad de acordar la celebración del juicio a puerta cerrada en el artículo 680.2 en los casos en que así lo exijan razones de moralidad o de orden público o el respeto debido a la persona ofendida o a su familia ${ }^{14}$.

La celebración del juicio a puerta cerrada supone, en definitiva, una limitación a la libertad de información en cuanto que impide el acceso a la sala de vistas, donde se desarrolla el acto del juicio oral, a cualquier persona ajena al proceso $\mathrm{y}$, por tanto, a los medios de comunicación, lo que les imposibilita el acceso directo a la fuente de la noticia.

Los motivos por los cuales puede acordarse la celebración del juicio a puerta cerrada constituyen un numerus clausus y, en principio, vienen determinados por las causas recogidas en el propio artículo 680.2 de la LECrim, completado con lo dispuesto en la LOPJ'5. La regulación contenida en los textos legales sobre esta materia hemos visto que es escasa y difícilmente puede considerarse suficiente para afrontar las exigencias que se derivan de la actual relevancia del principio de publicidad, significativamente afectado por el papel que

13 «Excepcionalmente, por razones de orden público y de protección de los derechos y libertades, los Jueces y Tribunales, mediante resolución motivada, podrán limitar el ámbito de la publicidad y acordar el carácter secreto de todo o parte de las actuaciones".

14 Dispone el citado artículo que: «Podrá, no obstante, el Presidente mandar que las sesiones se celebren a puerta cerrada cuando así lo exijan razones de moralidad o de orden público, o el respeto debido a la persona ofendida por delito o a su familia. Para adoptar esta resolución, el Presidente, ya de oficio, ya a petición de los acusadores, consultará al Tribunal, el cual deliberará en secreto, consignando su acuerdo en auto motivado, contra el que no se dará recurso alguno".

15 En otras normas procesales penales también se hace referencia a la posibilidad de celebrar el juicio a puerta cerrada. La Ley 35/1995, de 11 de diciembre, de ayuda y asistencia a las víctimas de delitos violentos y contra la libertad sexual, encomienda expresamente al Ministerio Fiscal, en su artículo 15.5, la protección de la víctima de toda publicidad no deseada pudiendo solicitar la celebración a puerta cerrada del juicio de conformidad con lo previsto en la Ley de Enjuiciamiento Criminal. En la Ley Orgánica 5/2000 reguladora de la Responsabilidad Penal de los Menores se prevé, en el artículo 35.2, que el Juez pueda acordar, en interés de la persona imputada o de la víctima, que las sesiones no sean públicas. Del mismo modo, en el artículo 63.2 de la Ley Orgánica 1/2004, de medidas de protección integral contra la violencia de género, se prevé que los Jueces puedan acordar de oficio o a instancia de parte que la vista se desarrolle a puerta cerrada. 
en la actual sociedad tienen los medios de comunicación, sobre todo los audiovisuales.

El artículo 680 de la LECrim establece que es al Presidente del Tribunal al que le corresponde acordar, en su caso, la celebración del juicio a puerta cerrada; para la adopción de esta resolución el Presidente actuará de oficio o a petición de los acusadores, tras consultar al Tribunal, el cual deliberará en secreto, consignará su acuerdo en auto motivado, contra el que no se dará recurso alguno ${ }^{16}$. Este artículo se contiene dentro de la regulación del Procedimiento Ordinario o de Sumario; aunque dado el carácter subsidiario de la regulación de este procedimiento, dicha posibilidad es igualmente admisible para el resto de procedimientos previstos en la LECrim $^{17}$.

En conclusión, podemos considerar que son necesarios tres requisitos para acordar la celebración de un juicio a puerta cerrada: primero, inclusión en uno de los supuestos legalmente previstos; segundo, motivación del acuerdo; y por último, seguimiento estricto de los términos en que se haya fijado la limitación de la publicidad ${ }^{18}$. En todo caso, las eventuales prohibiciones o limitaciones del principio de publicidad deberán sujetarse al principio de proporcionalidad, de este modo la limitación tendrá un carácter absoluto sólo en aquellos casos en que la necesaria protección de los derechos y bienes jurídicos afectados así lo exija y no pueda conseguirse con la utilización de otros medios; en otro caso, la protección deberá realizarse mediante la adopción de medidas que limiten la publicidad en la medida estríctamente imprescindible.

Las posibilidades de limitar el principio de publicidad en la fase de juicio oral no se reducen exclusivamente al acuerdo de celebración del juicio a puerta cerrada; entre la drástica resolución que supone la

16 No obstante la aparente sencillez y claridad de lo expuesto son diversas las cuestiones que pueden plantearse y que no han sido previstas por el legislador. Por ejemplo, nada dice la Ley de Enjuiciamiento Criminal respecto a la posibilidad de que la celebración a puerta cerrada sea instada por los propios procesados, posibilidad que debe admitirse en congruencia con el derecho de defensa y el principio de igualdad de armas. Tampoco parece que quepa excluir la posibilidad de que dicho acuerdo se pueda tomar tanto antes de comenzar el juicio, como en cualquier momento del mismo o incluso que, durante la celebración del mismo pueda revocarse o modificarse una resolución previamente adoptada por el Tribunal respecto a las limitaciones que debe sufrir el principio de publicidad.

17 Aunque se emplee el término consulta debe entenderse que el acuerdo corresponde al trío de magistrados; por lo que la decisión ha de ser colegiada. GARCÍA PÉREZ, S.F.: "La televisión desde la sala del juicio en los procesos penales», en Revista del Poder Judicial, número especial XVII. CGPJ, Madrid, 1999, p. 231.

18 Así lo exige el Tribunal Supremo en la sentencia 168/1995, de 14 de febrero. 
exclusión total de cualquier persona ajena al proceso al acto de la vista y el libre acceso de cualquier ciudadano a la sala donde se va a celebrar el juicio, cabe la posibilidad de adoptar una serie de medidas intermedias o restricciones de carácter parcial. El propio artículo 232.2 de la LOPJ se refiere expresamente a la posibilidad de «limitar el ámbito de la publicidad». La facultad de adoptar otro tipo de limitaciones, que no supongan la celebración de la totalidad del juicio a puerta cerrada, permiten que el órgano jurisdiccional, en el momento de adoptar la resolución limitativa, pueda efectuar un más ajustado y correcto juicio de proporcionalidad o ponderación, reduciendo al mínimo la afectación del principio de publicidad. De este modo, el derecho a un proceso público y a la libertad de información quedan limitados en la medida estrictamente indispensable para la protección de los bienes jurídicos o derechos en peligro. En este sentido el mismo artículo 6 del Convenio de Roma y el artículo 14 del Pacto Internacional de Derechos Civiles y Políticos contemplan expresamente la posibilidad de prohibir el acceso a la Sala de Audiencia «durante la totalidad o parte de los juicios».

El establecimiento de límites parciales ofrece un amplio abanico de posibilidades, así, pueden fijarse límites de carácter personal, mediante la prohibición de acceso a la sala de determinadas personas; de carácter temporal, acordando que se celebren a puerta cerrada únicamente determinadas diligencias probatorias; o bien de carácter técnico o material, referidas a la exclusión de la entrada de determinados medios técnicos de captación o difusión de la imagen como podrían ser las cámaras fotográficas, de vídeo o televisión.

\section{EL ACCESO DE LOS MEDIOS DE COMUNICACIÓN}

Analizado brevemente el significado del principio de publicidad, así como las limitaciones que pueden imponerse al mismo, estamos en condiciones de analizar el alcance que dicho principio tiene cuando lo vinculamos directamente con los medios de comunicación, así como cuáles son los presupuestos y condiciones que determinan el acceso a las salas de justicia de dichos medios, especialmente cuando se trata de medios de comunicación audiovisuales.

El principio de publicidad, entendido en su sentido más amplio como publicidad externa, se ve reforzado con la presencia de los medios de comunicación. Si el principio de publicidad de los juicios pretende que éstos sean conocidos más allá del círculo de los intervinientes en los mismos, los medios de comunicación superan las limitaciones de espacio, tiempo y lugar, permitiendo que un acto ju- 
dicial pueda ser conocido por un elevado numero de personas; pues resulta evidente que el número de personas que pueden presenciar in situ un juicio, y por tanto tener una percepción directa de las actuaciones procesales que se desarrollan en el mismo, es indefectiblemente escaso y limitado. Sólo a través de los medios informativos se puede hacer llegar al ciudadano una noticia que no está en condiciones de conocer directamente, permitiendo, en definitiva, que se efectúe el control de la actividad judicial por parte de los ciudadanos.

En el principio 12 de la Recomendación (2003)13 del Comité de Ministros del Consejo de Europa sobre divulgación de información a través de los medios de comunicación con respecto a procedimientos penales, se establece que se debe permitir la entrada de periodistas, sin discriminación alguna, a las vistas públicas, sin que puedan ser excluidos a menos que el público también lo sea.

Dos son los principios básicos que se pueden aplicar a la cuestión del acceso de los medios de comunicación a las actuaciones judiciales. En primer lugar, debemos considerar a los medios como los intermediarios naturales entre la noticia, en este caso el proceso, y los ciudadanos; en segundo lugar, y precisamente a consecuencia de esta relevante función desarrollada, los medios tienen un derecho de preferencia a la hora de acceder a las actuaciones judiciales. El Tribunal Constitucional, en la importante sentencia 30/1982, ya se refirió a estas dos ideas, haciendo expresa referencia a las mismas. Así, los medios de comunicación van a permitir que la noticia se conozca más allá del limitado número de personas que pueden acceder a la sala de justicia ${ }^{19}$. Por otro lado, el derecho de acceso preferente de los medios no puede considerarse, en modo alguno, como un privilegio discrecional ${ }^{20}$.

No podemos olvidar que el acceso de los medios de comunicación a las salas de vistas no sólo se fundamenta en el principio de publicidad

${ }^{19}$ Señala nuestro más alto tribunal en la citada sentencia: «El principio de publicidad de los juicios, garantizado por la Constitución implica que estos sean conocidos más allá del círculo de los presentes en los mismos, pudiendo tener una proyección general. Esta proyección no puede hacerse efectiva más que con la asistencia de los medios de comunicación social, en cuanto tal presencia les permite adquirir la información en su misma fuente y transmitirla a cuantos....están en la imposibilidad de hacerlo. Este papel de intermediario natural desempeñado por los medios de comunicación social entre la noticia y cuantos no están, así, en condiciones de conocerla directamente, se acrecienta respecto a acontecimientos que por su entidad pueden afectar a todos».

${ }^{20}$ El Tribunal Constitucional se refiere también al segundo de los principios expuestos en los siguientes términos: «...los representantes de los medios de comunica- 
sino también en la raíz misma del derecho de información, pues una de las facultades que integra este derecho es la de garantizar el acceso a las fuentes de la noticia. Las audiencias públicas son una fuente pública de información y forma parte del contenido de la libertad de informar que no se impida el acceso a la mencionada fuente ${ }^{21}$.

Hemos visto cómo la resolución judicial por la que se acuerda la celebración de un juicio a puerta cerrada supone una limitación del principio de publicidad y en consecuencia un límite a la información que sobre estos actos pueda realizarse. La resolución por la que se acuerda que un juicio ha de celebrarse sin la presencia de público, impedirá el acceso a la Sala de cualquier persona así como de cualquier medio de comunicación.

El artículo 6 del Reglamento 1/2005, de los aspectos accesorios de las actuaciones judiciales ${ }^{22}$, se refiere expresamente a la posibilidad de denegar el acceso de los medios de comunicación a los actos procesales celebrados en audiencia pública mediante resolución motivada del Juez o Presidente del Tribunal en los supuestos en que puedan verse afectados valores y derechos constitucionales. Como aspecto positivo de este artículo se puede señalar que el Reglamento recoge una cláusula genérica, evitando hacer un listado de cuáles son los derechos o valores constitucionales concretos que pueden fundamentar la adopción de la medida; en cualquier caso, la resolución que se adopte corresponderá al Juez o Presidente del Tribunal y deberá ser motivada ${ }^{23}$.

ción social, al asistir a las sesiones de un juicio público, no gozan de un privilegio gracioso y discrecional, sino que lo que se ha calificado como tal es un derecho preferente atribuido en virtud de la función que cumplen, en aras del deber de información constitucionalmente garantizado".

${ }_{21}$ Recordemos que el artículo 19 de la Declaración Universal de Derechos Humanos, aprobada el 10 de diciembre de 1948, establece que la libertad de opinión y expresión incluye el derecho de investigar. Como señala ESCOBAR DE LA SERNA la facultad de investigar forma parte del derecho de información, y debe entenderse como la facultad de acceder directamente a las fuentes de las informaciones; ESCOBAR DE LA SERNA, L.: Derecho de la Información. Dykinson, Madrid, 2004, pp. 80 y 81. En la misma línea, LOPEZ ORTEGA considera que el derecho a indagar en las fuentes es consecuencia de la conexión entre libertad de información y régimen democrático que conlleva un derecho de acceso de los medios a aquellos lugares en los que la noticia se produce; en «Información y Justicia», op. cit., pp. 93 y ss.

22 Aprobado por Acuerdo de 15 de septiembre de 2005 por el Pleno del CGPJ. El artículo supone una novedad en cuanto hace, únicamente, referencia a los medios de comunicación.

${ }_{23}$ El citado artículo se refiere a una resolución motivada por la que expresamente se deniega el acceso a los medios de comunicación acreditados, pero surge la duda si dicha resolución debe ser jurisdiccional o gubernativa, y si puede ser recurrida por los medios afectados y en qué forma. 


\section{EL ACCESO DE LOS MEDIOS AUDIOVISUALES}

\subsection{EFECTOS QUE PRODUCE LA PRESENCIA DE LOS MEDIOS AUDIOVISUALES}

Indudablemente, la cobertura audiovisual de un acto judicial aporta una serie de consecuencias, no todas ellas positivas, la primera de las cuales se evidencia en la nueva dimensión cuantitativa y cualitativa que adquiere el principio de publicidad de las actuaciones procesales; lo que puede generar una serie de problemas antes inexistentes o bien agravar otros que ya estaban presentes con anterioridad.

Sin ánimo de ser exhaustivos nos podemos referir a diversos efectos positivos o negativos que se derivan de la presencia de los medios audiovisuales. Así, dentro de las ventajas que presenta la cobertura radiofónica o televisiva, se encuentra sin duda el potencial número de espectadores con que cuentan estos medios, fundamentalmente la televisión, por lo que se incrementa considerablemente el número de personas receptoras. De este modo se produce un reforzamiento de la función de control por parte de los ciudadanos de la Administración de Justicia. Lógicamente son los propios periodistas los que ponen el acento en las ventajas que supone el tratamiento televisivo de los procesos criminales, criticando las reticencias que a los juristas les produce dicha posibilidad; sirva como ejemplo la opinión del periodista DEL VAL VELILLA, el cual aboga por una grabación y emisión del juicio del principio al fin, lo que evitaría manipulaciones y aportaría los siguientes ventajas: veracidad absoluta, las partes serán mucho más escrupulosas ante la presencia de las cámaras; las cámaras acercan la Justicia a la sociedad y fortalecen el respeto al sistema, las cámaras son garantes de un juicio objetivo e imparcial y aseguran que el juicio se desarrolle con la necesaria dignidad ${ }^{24}$.

Por el contrario, los inconvenientes con que nos encontramos también son numerosos. Las posibilidades técnicas de toma, montaje y posterior difusión de imágenes se prestan a posibles manipulaciones y utilización sesgada o tendenciosa de las mismas. Cierto es que el riesgo de distorsión también se encuentra presente en la crónica literaria o la realización de un dibujo, pero la enorme difusión de la cobertura televisiva genera una agravación cuantitativa del problema. Con todo, los inconvenientes más graves se centran, a nuestro

${ }^{24}$ DEL VAL VELILLA, L.: «El tratamiento televisivo de las noticias criminales", en Revista del Poder Judicial, Número Especial XVII. CGPJ, Madrid, 1999, pp. 239 y 240. 
juicio, en la incidencia que tales medios pueden tener en derechos constitucionalmente protegidos, principalmente en la propia imagen, sin olvidar los derechos al honor y la intimidad; pero no sólo éstos, también pueden verse afectados el derecho a la vida y la integridad física de peritos o testigos.

No resulta tampoco baladí la influencia que los medios pueden tener en la recta administración de justicia, a que se refiere el artículo 138.2 de la Constitución, pues la presencia de medios audiovisuales en la sala puede originar perturbaciones en el normal desarrollo del proceso, al introducir connotaciones de espectáculo e influir en el comportamiento que, en el acto de la vista, pueden tener todos y cada uno de los intervinientes en la misma. Esta influencia es mayor, lógicamente, en quienes no están habituados a intervenir en actos judiciales, actuando ocasionalmente en los mismos ya sea en calidad de acusados, testigos o peritos, aunque tampoco puede descartarse esta incidencia en los propios profesionales, como abogados e incluso jueces y fiscales.

Otro de los inconvenientes vendría determinado por la posibilidad de que una presencia masiva e indiscriminada de las cámaras origine, alimente o facilite el fenómeno del juicio paralelo, de tal manera que el proceso, además de en sede judicial, pase a desarrollarse en los propios medios de comunicación.

En ocasiones, el problema de la presencia de los medios audiovisuales viene determinado por el modo el que se utilizan las imágenes obtenidas, particularmente por el formato del programa en el que se emiten ${ }^{25}$.

\subsection{EL ACCESO DE LOS MEDIOS DE COMUNICACIÓN EN EL DERECHO INTERNO}

Dejando al margen la cuestión de la celebración de los juicios a puerta cerrada, pues se trata de una limitación que afecta al aspecto externo de la publicidad, tanto mediata como inmediata; cabe preguntarse cómo se regula el acceso de los medios de comunicación a los Tribunales de Justicia, en especial en lo que se refiere a la pre-

${ }^{25}$ Sobre esta cuestión reflexiona LÓPEZ ORTEGA, y es que no produce los mismos efectos la emisión de determinadas imágenes, obtenidas en la sala de vistas, en un programa informativo que en un programa de variedades, en «Información y Justicia», en Justicia y Medios de Comunicacion, Cuadernos de Derecho Judicial n. ${ }^{\circ}$ XVI (2006), CGPJ, Madrid, 2007, pp.120 a 122. 
sencia de éstos en el acto del juicio oral ${ }^{26}$. Ante todo hemos de destacar la tradicional ausencia de normativa legal expresa a este respecto; existen unos principios generales que pueden resumirse en las dos ideas anteriormente expuestas, pero la sola aplicación de unos principios tan genéricos no sirve para resolver la gran diversidad de problemas que la presencia de los medios pueden originar, sobre todo cuando se trate de medios de comunicación audiovisuales.

La ausencia de disposiciones normativas sobre las condiciones de acceso de los medios audiovisuales determinó que, en principio, fueran los propios Jueces o Tribunales encargados del enjuiciamiento de los asuntos, los que haciendo uso de las funciones que les atribuye la policía de estrados, decidiesen sobre la cuestión. Así la LOPJ, en su artículo 190.1, dispone que corresponde al Presidente del Tribunal o al Juez mantener el orden en la Sala, a cuyo efecto acordará lo que proceda. De hecho, se fue generalizando una opinión favorable a la presencia de los medios de comunicación audiovisuales en las audiencias penales fundamentada, precisamente, en la ausencia de prohibición u obstáculos de carácter legal ${ }^{27}$.

De este modo y ante la situación de vacío legal, fueron los órganos de gobierno de los Tribunales los que, a través de las Salas de Gobierno, adoptaron acuerdos para establecer una normativa de regulación del acceso de los medios de comunicación a las salas de juicios amparándose en las facultades gubernativas que están atribuidas a los mismos conforme a lo dispuesto en la LOPJ ${ }^{28}$.

26 Debe entenderse que existe una prohibición de carácter residual de acceso a las instalaciones de los Tribunales cuando no va a tener lugar ninguna actividad jurisdiccional o gubernativa de carácter público; las normas que regulan el secreto del sumario impiden el acceso de los profesionales de la información a las dependencias judiciales en donde hayan de practicarse tales diligencias que no tienen carácter público. No puede olvidarse que el principio de publicidad no es de aplicación a todas las fases del proceso penal, sino tan sólo a la fase de juicio oral y a la de ulterior sentencia. Como indica el Tribunal Constitucional en la STC 56/2004, en su fundamento jurídico $6 .^{\circ}$, los pasillos $\mathrm{u}$ otras dependencias no son fuente de información de acceso general, pues más allá de los locales en que se desarrollan las actuaciones públicas, el derecho de acceso tiene un carácter instrumental, es decir, como medio para llegar a aquellos locales.

${ }^{27}$ LOPEZ ORTEGA, J.J.: «La dimensión constitucional del principio de publicidad de la justicia», op. cit., p.110.

${ }_{28}$ Una de las primeras resoluciones, dictada por nuestros tribunales, que hizo referencia a los problemas generados por la presencia de medios audiovisuales en las Salas de Vistas data del año 1987, con ocasión de la celebración del denominado «Juicio de la Colza». Para regular el acceso de los medios, la Audiencia Nacional dictó una providencia en la que se refería a la reserva de asientos, la toma de notas, la toma de imágenes y la transmisión de imágenes y sonido. Otro ejemplo de esta práctica lo 
Las normas dictadas solían ser bastantes restrictivas en lo que se refería al acceso de los medios audiovisuales a las salas de vistas, pero la evolución de la doctrina jurisprudencial en esta materia ha sido muy rápida y queda perfectamente reflejada en el iter procesal seguido por los recursos que en su día se interpusieron contra un acuerdo adoptado, en esta materia, por la Sala de Gobierno del Tribunal Supremo en el año 1995, y a los que nos vamos a referir a continuación.

\subsection{LA DOCTRINA ESTABLECIDA POR EL TRIBUNAL CONSTITUCIONAL EN LAS SENTENCIAS 56/2004 Y $57 / 2004$}

Con fecha 12 de septiembre de 1995, la Sala de Gobierno del Tribunal Supremo aprobó unas Normas sobre el acceso al palacio sede del Tribunal Supremo, de las cuales la sexta, relativa al acceso al Palacio de los medios de comunicación social, establecía que, salvo en determinados actos gubernativos solemnes, como la apertura del año judicial, era necesaria la autorización expresa para el acceso de los periodistas, prohibiendo el acceso de cámaras fotográficas y de televisión a las salas de vistas ${ }^{29}$. Tras la adopción del acuerdo se hizo llegar un escrito al Presidente del Tribunal Supremo en el que determinados periodistas solicitaban la revocación o modificación del mismo, la Sala de Gobierno mantuvo el mismo criterio restrictivo, si bien se reconocía el derecho de acceso preferente de los medios ${ }^{30}$.

constituye el conjunto de reglas que dictó el Tribunal Superior de Justicia de Andalucía contenidas en un acuerdo que entró en vigor el día 1 de junio de 1996; el acuerdo establecía una prohibición genérica de utilización de medios audiovisuales, salvo para actos gubernativos y condicionaba la labor de los periodistas a la previa obtención de una credencial.

${ }^{29}$ El contenido del acuerdo era el siguiente: «1. En el Acto de Apertura del Año Judicial, tomas de posesión y demás actos gubernativos solemnes se facilitará el acceso de los medios de comunicación social en general, y de las televisiones públicas y privadas en particular, que lo soliciten de la Secretaría de Gobierno, que extenderá las pertinentes acreditaciones y tomará las disposiciones necesarias para que los expresados medios puedan cumplir su misión informativa sin menoscabo del acto que haya de celebrarse. Lo anterior se entiende sin perjuicio de las competencias propias de los Servicios de Seguridad. 2. Fuera de los mencionados actos, el acceso de los medios de comunicación al Palacio requerirá autorización expresa de la Presidencia del Tribunal Supremo. 3. No se permitirá el acceso de los indicados medios con cámaras fotográficas o de televisión a juicios o vistas en ninguna de las Salas».

${ }^{30}$ La Sala de Gobierno del Tribunal Supremo, con fecha 25 de septiembre, sustituyó la norma anterior por otra, en la que seguía estableciendo la prohibición abso- 
Posteriormente se interpusieron sendos recursos administrativos ordinarios ante el Pleno del Consejo General del Poder Judicial, que concluyeron que el acuerdo adoptado no vulneraba el derecho de información ni el principio de publicidad ${ }^{31}$. No obstantè, sí se estimaron parcialmente los recursos interpuestos respecto a lo dispuesto en el apartado tercero del acuerdo de la Sala de Gobierno, al considerarse que en el mismo no se respetaban las facultades jurisdiccionales de las Salas para autorizar, en cado caso, el acceso de medios audiovisuales a las vistas; se señalaba que no era la Sala de Gobierno la que era competente para adoptar decisiones sobre el acceso de los medios audiovisuales a las vistas, sino que tal decisión correspondía a cada una de las Salas del Tribunal Supremo, de tal modo que las competencias gubernativas estaban subordinadas a las funciones jurisdiccionales ${ }^{32}$.

Los recurrentes interpusieron sendos recursos contencioso-administrativos ante la Sala Tercera del Tribunal Supremo. Estos recursos fueron acumulados y resueltos por la Sentencia de 9 de julio de 1999 dictada por la sección Séptima de la Sala de lo Contencioso-Administrativo del Tribunal Supremo que los desestimó totalmente. La

luta de acceso con cámaras de televisión, video o fotográficas a los actos jurisdiccionales, sin embargo, en el nuevo acuerdo, ya se hacía expresa mención del derecho de acceso preferente del que gozan los medios. Ante el malestar y las quejas de la Asociación de la Prensa de Madrid, la Sala de Gobierno del Tribunal Supremo, en sesión de 5 de octubre de 1995, adoptó un nuevo acuerdo en el que no hizo sino reafirmarse en el acuerdo adoptado con anterioridad.

31 El acuerdo no convenció a los periodistas, cuya disconformidad fue en aumento, por lo que el siguiente paso que dieron fue la interposición de sendos recursos administrativos ordinarios ante el Pleno del Consejo General del Poder Judicial por parte de la Federación de Asociaciones de Prensa y por parte de algunos periodistas a título particular. Los dos recursos se resolvieron por acuerdo de 7 de Febrero de 1996, siendo ambos desestimados casi en su totalidad, al entender que el acuerdo adoptado no vulneraba el derecho de información ni el principio de publicidad, justificando la prohibición de acceso de los medios audiovisuales en el deber «...de asegurar a todos los que participan en tales actos (peritos, testigos, partes, e incluso el propio Tribunal) que sus cometidos podrán desarrollarse serenamente, sin presión alguna».

${ }^{32}$ La consecuencia práctica era que cada Juez o Tribunal es soberano para decidir, oídas las partes y el Ministerio Fiscal, sobre cualquier cuestión que pudiera afectar al principio de publicidad del proceso. Así, las facultades gubernativas que se reconocen a los órganos de gobierno de los Tribunales para dictar normas generales de utilización del edificio, están subordinadas a las que en el ejercicio de la función jurisdiccional puedan adoptar las Salas de Justicia en garantía del principio de publicidad de los juicios, pudiendo, por tanto ampliar, restringir o incluso condicionar dicha publicidad, debiendo comunicar la resolución adoptada a la Sala de Gobierno para que la lleve a efecto y adopte las medidas necesarias para asegurar su debido cumplimiento. 
Sala Tercera consideró que la prohibición genérica de acceso con cámaras fotográficas, de televisión o de video al Palacio del Tribunal Supremo, salvo en los actos de apertura del año judicial, tomas de posesión y actos gubernativos solemnes, preservando las facultades de cada una de las Salas para autorizar en cada caso el acceso de los medios audiovisuales a la vistas, no vulneraba el derecho a la libre información ${ }^{33}$.

El punto final de este largo proceso lo constituyeron sendos recursos de amparo interpuestos por los demandantes que fueron resueltos por el Tribunal Constitucional por medio de las sentencias $56 / 2004$ y 57/2004, de 19 de abril ${ }^{34}$. La importancia de estas sentencias radica en que definen y asientan la doctrina aplicable sobre las relaciones entre la libertad de información y el principio de publicidad de las actuaciones judiciales, modificando los criterios que tradicionalmente se habían seguido respecto al acceso de los medios de comunicación audiovisuales. Las sentencias parten de la consolidada doctrina existente sobre la relación entre el derecho a comunicar o recibir libremente información veraz y el principio de publicidad de las actuaciones judiciales; considerando a los medios de comunicación como un intermediario natural entre la noticia y los ciudadanos.

Pero el Tribunal Constitucional, en este caso, no se detiene aquí sino que va más allá, al advertir la importancia de poder acceder a la

${ }^{33}$ La Sentencia indicaba cómo el aspecto gubernativo de la prohibición de acceso se ve amparado por las competencias que a las Salas de Gobierno atribuye el artículo 152.1 de la LOPJ y el artículo 4 del Reglamento 4/1995 de 7 de Junio, entre las cuales se encuentran la de establecer a propuesta del Presidente, las normas generales para regular el acceso a las instalaciones del Tribunal y la utilización de sus servicios y dependencias. En lo que concierne al aspecto jurisdiccional, es decir, a las facultades que cada una de las Salas de Justicia tienen para adoptar las medidas oportunas en relación al acceso de medios audiovisuales a las vistas, sólo respecto a cada resolución en particular podrá o no hablarse de infracción del principio de publicidad consagrado en el artículo 120 de la Constitución.

${ }^{34}$ La sentencia 56/2004 resuelve el recurso de amparo promovido por un grupo de periodistas, mientras la sentencia 57/2004 resuelve el recurso de amparo interpuesto por la Federación de Asociaciones de la Prensa Española El contenido de ambas sentencias es sustancialmente idéntico pues resuelven sendos recursos interpuestos contra los Acuerdos de la Sala de Gobierno del Tribunal Supremo que aprobaba las normas sobre acceso al Palacio de 12 y 25 de septiembre de 1995, así como el Acuerdo de 7 de febrero de 1996 que modificaba parcialmente el contenido de aquéllos. La única diferencia existente entre las dos resoluciones se encuentra en el fundamento jurídico sexto, puesto que mientras la STC 56/2004 se pronuncia sobre el apartado primero de los citados acuerdos, la STC 57/2004 se pronuncia sobre el apartado segundo. El resto de fundamentos jurídicos así como el voto particular existente es idéntico en ambos pronunciamientos. 
fuente de la noticia, manifestando que: «si la noticia se obtiene en una fuente de información de acceso general, como son las audiencias públicas judiciales, forma parte del contenido del derecho a la libertad de información que no se impida el acceso a la mencionada fuente» ${ }^{35}$.

Las sentencias analizan, a continuación, si todas las consideraciones expuestas, que ningún problema plantean cuando de la prensa escrita se trata, pueden extenderse a los medios de comunicación audiovisuales. La respuesta es positiva, puesto que el artículo 20.1.d de la Constitución garantiza el derecho a comunicar libremente información veraz por «cualquier medio de difusión». El Tribunal es suficientemente expresivo al manifestar que «nada distinto de lo declarado para los periodistas que cumplen su función mediante el escrito hay que decir para las informaciones que se valen de otros medios técnicos para obtener y transmitir la noticia», añadiendo que "ha de destacarse que la imagen enriquece notablemente el contenido del mensaje que se dirige a la formación de una opinión pública libre ${ }^{36}$.

El Tribunal Constitucional, no obstante, no es ajeno a los peculiares problemas que plantea la difusión de información procesal a través de medios audiovisuales, y la forma en que determinados derechos constitucionales y otros bienes jurídicamente protegidos pueden verse especialmente afectados; de forma más significativa el derecho a la propia imagen, así como el derecho al honor, la intimidad, e incluso el derecho a la vida y la integridad personal. La captación de imágenes en el curso de un proceso, además, puede provocar efectos intimidatorios en los intervinientes en el mismo, favorecer la aparición de un juicio paralelo o simplemente perjudicar el normal y ordenado desarrollo del proceso necesario para una correcta administración de justicia. Todos estos efectos perjudiciales no pueden obviarse a la hora de establecer eventuales limitaciones al acceso de los medios de comunicación audiovisuales y por tanto tendrán un carácter más restrictivo que las que pueden aplicarse a los medios de comunicación escritos. El Tribunal finaliza el planteamiento de la cuestión refiriéndose a las limitaciones y excepciones que puede sufrir el principio de publicidad de las actuaciones procesales, indicando que es el legislador, conforme a lo establecido en el propio artículo 120.1 de la Constitución, el que ha previsto aquellos supuestos en que la publicidad de las actuaciones judiciales puede ser limitada o excepcionada por los jueces.

${ }^{35}{\text { Fundamento jurídico } 30^{\circ}}^{\circ}$

${ }^{36}$ Fundamento jurídico $4 .^{\circ}$ 
La cuestión clave sobre la que se pronuncia el Tribunal Constitucional, es la posibilidad de acceso de los periodistas con cámaras fotográficas, de video o televisión ${ }^{37}$. Sobre este extremo el Tribunal Constitucional corrige el criterio que tradicionalmente había adoptado el Tribunal Supremo, al entender que el régimen de prohibición general que podía ser levantado, en cada caso, por autorización de la Sala de Justicia es incompatible con el derecho a comunicar libremente información. El principio que debe aplicarse es precisamente el contrario, es decir, el acceso de los medios audiovisuales a los juicios está inicialmente permitido, de tal forma que cualquier limitación o prohibición ha de realizarse expresamente, en cada caso, por el órgano judicial, con sujeción al principio de proporcionalidad ${ }^{38}$.

El Tribunal Constitucional ha variado, por tanto, el principio general que regulaba el acceso de los medios audiovisuales a los juicios orales y vistas públicas, de una prohibición general con reserva de autorización se ha pasado a un régimen de habilitación general con reserva de prohibición ${ }^{39}$.

${ }^{37}$ Las sentencias resuelven otras importantes cuestiones. Respecto al apartado primero del acuerdo impugnado, referido a la sujeción por parte de los profesionales a las normas de seguridad que se establezcan y a la necesidad de obtener acreditaciones, el Tribunal considera que el acuerdo no vulnera el derecho a la libre información, puesto que en nada afecta al mismo el cumplimiento de unas normas generales de seguridad, ni la previsión de acreditaciones o identificaciones, que, por el contrario, constituyen "un medio adecuado para que pueda ejercerse el derecho de acceso preferente a la audiencia». En relación al apartado segundo del acuerdo impugnado el Tribunal Constitucional considera que no vulnera el derecho de información puesto que no pretende constituir al Gabinete Técnico y a la Sala de Prensa como la única fuente a la que puedan acudir los informadores para obtener la noticia, lo que se pretende es establecer un canal informativo adicional y complementario.

38 Señala el Tribunal en el fundamento jurídico $70^{\circ}$ de ambas sentencias: «...ha de entenderse que este régimen de prohibición general con reserva de autorización es incompatible con la normativa reguladora del ejercicio del derecho fundamental a la libertad de información actualmente vigente, que establece, conforme a lo que ya se ha expuesto, precisamente, una habilitación general con reserva de prohibición. A la ley está reservada la regulación de las excepciones a la publicidad del proceso (SSTC 96/1987, de 10 de junio, FJ.2; y 65/1992, de 29 de abril, FJ. 2), que son, al mismo tiempo, para las actuaciones que se pueden celebrar en régimen de audiencia pública, límites de la libertad de información (ATC 195/1991, de 26 de junio, FJ. 6). Mientras el legislador, de acuerdo con las exigencias del principio de proporcionalidad y de la ponderación, no limite con carácter general esta forma de ejercicio de la libertad de información, su prohibición o limitación en cada caso forman parte de la competencia que la Ley Orgánica del Poder Judicial y las distintas leyes procesales atribuyen a los Jueces y Tribunales para decidir sobre la limitación o exclusión de la publicidad de los juicios, competencia ésta que ha de ser también ejercida conforme al principio de proporcionalidad».

39 VIEIRA, F.J.: «Análisis y consecuencias de la sentencia del Tribunal Constitucional sobre la presencia de los medios audiovisuales en los juicios», en VV.AA., 
En consecuencia, el Tribunal Constitucional anula el apartado tercero de la norma sexta del acuerdo de la Sala de Gobierno del Tribunal Supremo. La nueva interpretación parece más acorde con la doctrina que habitualmente ha seguido el Tribunal Constitucional en cuestiones referentes al establecimiento de limitaciones al ejercicio de derechos fundamentales ${ }^{40}$. Resulta más adecuado que sea una resolución expresa, adoptada por el órgano jurisdiccional, la que limite o exceptúe el acceso de medios audiovisuales a los juicios que no establecer con carácter genérico una limitación cautelar, aunque la misma pudiera ser levantada en casos $\operatorname{concretos}^{41}$.

Deberá ser, por tanto, cada Juez o Tribunal, en el ejercicio de sus propias facultades jurisdiccionales y tras efectuar una cuidadosa ponderación de la totalidad de los derechos y bienes jurídicos que pueden verse afectados, el que pueda establecer de forma expresa y motivada prohibiciones o limitaciones al acceso de los medios audiovisuales a las salas de vistas ${ }^{42}$.

Nuevos retos y perspectivas de investigación en la comunicación. Fundación General de la Universidad Complutense, Madrid, 2005, pp. 595 a 600. Para este Magistrado las sentencias del Tribunal Constitucional han supuesto un cambio menor de lo que a primera vista pudiera parecer, pues considera que, en definitiva, siempre será necesaria una resolución judicial que pondere los derechos y bienes jurídicos en juego y que establezca las condiciones concretas de acceso.

${ }^{40}$ Una consolidada doctrina jurisprudencial exige que estas limitaciones cumplan los siguientes requisitos: que tengan cobertura legal expresa, que se adopten mediante resolución motivada y que las mismas se ajusten a un juicio de proporcionalidad y ponderación de los derechos e intereses jurídicos en juego.

41 Es obvio, ya lo hemos señalado, que el acceso de los medios audiovisuales a los juicios puede traer consigo efectos no deseados en aras a conseguir una recta administración de justicia o afectar a otros derechos constitucionales, pero resulta más adecuado que sea sólo entonces, cuando los órganos jurisdiccionales dicten acuerdos que prohíban o limiten el acceso de tales medios a la Sala de Vistas. En cualquier caso el peligro de que al espectador se le trasmita una versión deformada o simplemente no ajustada de lo que en realidad ha sucedido en el acto del juicio, existe sea cual sea el medio del que se valga el informador, ya sea oral, escrito o por medio de imágenes.

${ }^{42}$ Conviene resaltar la existencia de un voto particular en las sentencias 56/2004 y 57/2004 correspondiente al Magistrado Don Jorge RODRÍGUEZ-ZAPATA. Para este Magistrado la presencia de medios técnicos audiovisuales en el acto del juicio pueden incidir negativamente en su finalidad esencial, que es el hallazgo de la verdad procesal, así como en las garantías de un proceso justo, en la medida que lo que puede llegar a los espectadores es una "creación intelectual de quien informa y, por ello, como algo distinto de lo que se ha expresado o se ha visto en la Sala de Justicia». Derechos tales como el honor, la intimidad, la propia imagen, así como la necesidad de garantizar la autoridad e imparcialidad del poder judicial deben ser tenidos en consideración a la hora de pronunciarse sobre este aspecto. Para el Magistrado disidente los acuerdos anulados resultaban más favorables al derecho a comunicar información en cuanto garantizaban el acceso de los medios audiovisuales, tras la ponderación, que caso por caso, hiciera cada una de las Salas del Tribunal Supremo. 
En cualquier caso parece que, a falta de regulación sobre esta materia, será siempre necesaria algún tipo de resolución por parte del Juez o Magistrado-Presidente del tribunal enjuiciador; pues, aunque no se establezca ninguna clase de limitación o restricción al acceso de medios audiovisuales, es razonable considerar que será preciso fijar algún tipo de criterio o pauta a seguir que determine el modo en que estos medios acceden a la sala de vistas, para que su presencia no suponga un elemento perturbador que afecte al normal desarrollo del proceso. Compartimos la opinión de CARRILLO LÓPEZ para quien la nueva doctrina fijada por el Tribunal Constitucional no consagra un principio de acceso libre e indiscriminado de cámaras y fotógrafos al acto de la vista oral $^{43}$, tal posibilidad no es admisible para el correcto desenvolvimiento de la actividad jurisdiccional.

Un aspecto relevante de las sentencias analizadas viene constituido por el hecho de referirse el Tribunal Constitucional, expresamente, a un amplio abanico de posibilidades existentes a la hora de limitar el acceso de los medios audiovisuales. De este modo, la cuestión no se plantea únicamente en términos de prohibir o no el acceso de los mismos, sino también en la posibilidad de establecer una serie de medidas intermedias que sin limitar totalmente la posibilidad de entrada de los mismos en la sala de vistas, basten para la protección de los bienes jurídicos o derechos que pueden verse puestos en peligro ${ }^{44}$.

Aunque las sentencias no se refieren expresamente a la cuestión, parece lógico exigir que las resoluciones que el Juez o Tribunal adopte respecto a las posibles prohibiciones o limitaciones de acceso a los medios de comunicación audiovisuales deban estar motivadas y que, con carácter previo a su adopción, se dé audiencia a las partes.

Después de todo lo expuesto podemos considerar que las sentencias del Tribunal Constitucional marcan un antes y un después en todo lo que se refiere al acceso de los medios audiovisuales a las salas de vistas. La doctrina fijada determina que en España exista, en teo-

43 CARRILLO LÓPEZ, M.: «Configuración general del derecho a comunicar y recibir información veraz: Especial referencia a las relaciones entre Poder Judicial y medios de comunicación" en Justicia y Medios de Comunicación. Cuadernos de Derecho Judicial. CGPJ, Madrid, 2007, pp. 30-31.

${ }^{44}$ Concretamente, se refiere el Tribunal, en su fundamento jurídico $7 .^{\circ}$, a la «utilización de estos medios de captación y difusión de imágenes sólo antes, después y en las pausas del Juicio Oral, según las circunstancias del caso, o aplicarse la solución que se conoce como pool; o imponerse la obligación de tratar a posteriori las imágenes obtenidas para digitalizar determinados ámbitos de las mismas, de forma tal que no sean reconocibles determinados rostros». 
ría, uno de los regímenes más permisivos en Derecho Comparado respecto al acceso de los medios audiovisuales. De hecho, en la Recomendación (2003)13 del Comité de Ministros del Consejo de Europa, se dedica el principio 14 a la cobertura informativa emitida en directo y a la grabación en las salas de audiencias, fijando unos criterios de carácter más restrictivo y que, curiosamente, consagran la doctrina existente en España antes de las referidas sentencias del TC, esto es, la prohibición genérica de acceso con posibilidad de autorización ${ }^{45}$.

Las sentencias del TC no pueden considerarse como un punto final sino más bien como un punto de partida, puesto que son muchas las cuestiones que quedan sin resolver ${ }^{46}$. El propio Tribunal es consciente de la ausencia de una regulación de estas cuestiones, indicando que debe ser el legislador el que conforme a los principios de proporcionalidad y ponderación puede establecer límites generales a esta forma de ejercicio de la libertad de información ${ }^{47}$. Como hemos indicado, ante la falta de disposiciones legales, es a cada Juez o Tribunal al que le corresponde decidir sobre las prohibiciones o limitaciones de acceso de los medios audiovisuales, todo ello de acuerdo con un principio de proporcionalidad ${ }^{48}$.

\subsection{EL PROTOCOLO DE COMUNICACIÓN DE LA JUSTICIA}

La gran importancia de la doctrina establecida por estas sentencias se evidencia, en primer lugar, en el Protocolo de Comunicación de la Justicia ${ }^{49}$, el cual dedica un apartado a los medios de comuni-

45 Indica el citado principio: «Los medios de comunicación no podrán transmitir la información en directo desde la sala de audiencias ni grabar en ellas a menos que la legislación lo permita expresamente o así lo decidan las autoridades judiciales competentes». La Exposición de Motivos de la Recomendación considera que los permisos para emitir o grabar deben tener un carácter "expreso y excepcional" y deberán ofrecer un marco jurídico previsible y no discriminatorio.

${ }^{46}$ En este sentido VIEIRA se muestra partidario de un desarrollo legislativo de tales cuestiones, lo cual repercutiría en la uniformidad de las resoluciones que pudieran dictarse; en op. cit., p. 601.

47 Fundamento jurídico $7 .^{\circ}$

${ }^{48}$ LÓPEZ ORTEGA analiza cuáles son los factores que se pueden tener en consideración para limitar o no el acceso de los medios audiovisuales, y apunta los siguientes: el tipo de asunto, la posible influencia en la recta administración de justicia o en los derechos de las partes, el riesgo para los testigos, la posible interferencia con cualquier otra ley y el carácter escabroso o escandaloso del asunto. LÓPEZ ORTEGA, J.J.: "Información y Justicia»; op.cit., pp. 134 y 135.

49 Texto aprobado por la Comisión de Comunicación del CGPJ el 30 de junio de 2004 con el visto bueno del Pleno del propio CGPJ del día 7 de julio de 2004. 
cación audiovisuales. El texto se refiere tanto a la ausencia de una regulación legal referida al acceso a las salas de vistas, como a la doctrina asentada por la STC 57/2004, reconociendo, con carácter general, el libre acceso de los medios audiovisuales, confiriendo a las restricciones que puedan operar en este ámbito un carácter excepcional $^{50}$.

El aspecto más significativo del Protocolo, en lo referente al acceso a los medios audiovisuales, se encuentra en el importante papel que se confiere a los Gabinetes de Comunicación atribuyéndoles la función de organizar y controlar el acceso de los medios audiovisuales a las salas de vistas. Por tanto, corresponderá a estos órganos la adopción de medidas tales como la de garantizar la existencia de plazas suficientes en las salas de vistas; la reserva de parte de las mismas para los medios de comunicación; la concesión, en los casos en que sea preciso, de las oportunas acreditaciones así como facilitar los medios técnicos y materiales para que los periodistas puedan desarrollar su labor. Los Gabinetes pueden constituirse en el instrumento idóneo a través del cual se pueden dirigir las peticiones de acceso de los medios, el Gabinete las hará llegar con la antelación suficiente al órgano jurisdiccional para que resuelva sobre las mismas.

En cualquier caso, y como establece el propio Protocolo, la labor de los Gabinetes se desarrollará en coordinación con los Presidentes de los Tribunales ${ }^{51} \mathrm{y}$, aunque no lo mencione el Protocolo, con los órganos judiciales encargados del enjuiciamiento del caso, que en último término son los que en virtud de su capacidad de "policía de estrados" pueden establecer limitaciones o restricciones al acceso a las salas de vistas. Por este motivo, sería conveniente que cualquier resolución del Juez o Tribunal por la que se acuerde la celebración de una juicio a puerta cerrada o por la que se establezca cualquier otro

50 Señala el Convenio que: «Atendiendo a los principios básicos establecidos por la sentencia del Tribunal Constitucional, que posibilita el acceso de cámaras al Tribunal Supremo, y aunque no existe ninguna ley en España que regule el acceso de los medios de comunicación audiovisuales a las salas de vistas, como así corresponde al afectar a un derecho constitucional como es el de la información, se entiende desde este Consejo que es necesario preservar, con carácter general, el libre acceso de los medios audiovisuales a las salas de vistas, resultando de todo punto imprescindible que, en los supuestos excepcionales en que se limite o restrinja el derecho de información de estos medios, se dicten resoluciones motivadas de tal restricción por los órganos judiciales competentes, en función de su capacidad de "policía de estrados».

51 Establece el Protocolo que corresponderá a los Gabinetes de Comunicación del Tribunal Supremo, de la Audiencia Nacional y de los Tribunales Superiores de Justicia, en coordinación con los Presidentes de los Tribunales, la organización y control del acceso de los medios audiovisuales a las salas de vistas. 
tipo de limitación al libre acceso a la sala de vistas sea puesta inmediatamente en conocimiento del respectivo Gabinete de Comunicación a fin de lograr dotar de una máxima efectividad a la misma.

\subsection{EL PAPEL DEL MINISTERIO FISCAL}

La Instrucción 3/2005 de la Fiscalía General del Estado sobre relaciones del Ministerio Fiscal con los Medios de Comunicación también se refiere expresamente a la cuestión relativa al acceso de los medios de comunicación al acto del juicio oral. Indica la Instrucción que el derecho de acceso de los medios estará subordinado, lógicamente, a que el juicio no se celebre a puerta cerrada puesto que en tal caso se prescinde absolutamente de la publicidad externa. No obstante, la Instrucción considera que se debe intentar dotar de la máxima operatividad al derecho a informar, admitiendo la posibilidad de establecer gradaciones a la hora de fijar límites al libre acceso a la sala de vistas ${ }^{52}$.

Otro apartado de la Instrucción se refiere expresamente a la posición que debe adoptar el Ministerio Fiscal respecto a las grabaciones audiovisuales en el acto del juicio oral; la Instrucción refleja la extraordinaria importancia que reviste la STC 57/2004 de 19 de abril, a que le otorga el papel de leading case en la materia, recogiendo en el texto la doctrina creada por la citada resolución. Respecto a la postura que debe adoptar el Ministerio Público en el momento de informar sobre la utilización o no de instrumentos de captación audiovisual por parte de los medios de comunicación, el criterio general será el de no oponerse a la grabación audiovisual. La negativa a la presencia de los medios audiovisuales habrá de fundamentarse en la concurrencia de factores que desaconsejen la utilización de dichos medios, debido a que puedan interferir en el normal desarrollo del proceso o por afectar de forma desproporcionada a otros intereses dignos de protección.

La Instrucción enumera una serie de criterios que los miembros del Ministerio Fiscal deben ponderar en el momento de informar sobre esta cuestión. Estos criterios pueden resumirse en la necesidad

52 Concretamente establece la citada Instrucción al respecto: «cuando concurren causas debidamente justificadas de interés público a favor de una publicidad mediata limitada, y siempre que la naturaleza de la causa en la que se funde la restricción lo permita, no se opondrá (el Ministerio Fiscal) a que se permita la asistencia de prensa con las modulaciones que resulten procedentes". 
de proteger otros derechos o bienes jurídicos susceptibles de protección. La Instrucción se refiere expresamente a los siguientes aspectos que deben ser tenidos en consideración: derecho al honor, a la intimidad y propia imagen de las personas que intervienen en el proceso, derecho a la vida e integridad física, necesidad de garantizar un correcto y ordenado desarrollo del proceso, la presencia de personas en el proceso dignas de especial protección como menores o disminuidos psíquicos, la preservación del orden público, el interés informativo y trascendencia pública del caso, el carácter público o privado de la persona enjuiciada, la naturaleza del delito enjuiciado, la conveniencia de evitar el desarrollo de los denominados juicios paralelos y las opiniones emitidas por las propias partes del proceso.

En definitiva, la Instrucción recomienda a los Fiscales que traten «de conciliar el máximo de facilidades a la labor informativa con la necesidad de evitar tanto la conversión del juicio en mero espectáculo como la perturbación del objetivo esencial del acto del juicio oral, que en definitiva, no es otro que la realización del valor justicia mediante la aplicación del Derecho con relación al caso sometido a enjuiciamiento».

Una característica singular y muy interesante de la Instrucción es que prevé que el Ministerio Fiscal pueda subordinar su posición favorable a la grabación audiovisual del acto del juicio al cumplimiento de ciertas normas deontológicas tales como la no emisión de las imágenes en programas-espectáculo. En tales casos, y ante el incumplimiento de dichos criterios, el Ministerio Público podrá interesar la revocación de la autorización para las sesiones que quedaran aún pendientes. Sin duda, este constituye un mecanismo que permite garantizar, en cierto modo, la adecuada utilización de las imágenes obtenidas en la sala de vistas.

\subsection{LA DIFICIL IMPLANTACIÓN DE LA DOCTRINA DEL TRIBUNAL CONSTITUCIONAL}

El primer reflejo normativo del contenido de las sentencias del TC se encuentra en el Acuerdo de 15 de septiembre de 2005, del Pleno del CGPJ, por el que se aprueba el Reglamento 1/2005, de los aspectos accesorios de las actuaciones judiciales, que establece en su artículo 6: «Se permitirá, con carácter general, el acceso de los medios de comunicación acreditados a los actos procesales celebrados en audiencia pública, excepto en los supuestos en que pueda verse afectados valores y derechos constitucionales, en los que el Juez o 
Presidente del Tribunal podrá denegar dicho acceso mediante resolución motivada ${ }^{53}$.

No podemos sino lamentar la muy parca regulación que de tal cuestión se ha realizado por el Pleno del CGPJ, desaprovechando de esta manera una oportunidad inmejorable para hacer referencia y regular algunas de las muchas cuestiones que quedan sin resolver en esta materia. A la espera de una normativa que regule todos estos aspectos, resultaría interesante que las Salas de Gobierno de los Tribunales Superiores de Justicia, bajo el principio del respecto a las funciones jurisdiccionales de cada juez, adoptarán acuerdos en los que se fijaran ciertos criterios o recomendaciones de carácter organizativo en lo referente al modo en que puede hacerse efectivo el acceso de las cámaras a las salas de vistas, para tratar dotar de cierta uniformidad a las decisiones que se adopten por parte de los distintos órganos jurisdiccionales.

Es práctica habitual de los Tribunales la de permitir a los medios audiovisuales la toma de imágenes de los participantes minutos antes del comienzo de la vista ${ }^{54}$; este procedimiento suele bastar para cubrir las necesidades informativas de los medios, pues en la mayoría de las ocasiones la toma de imágenes obedece al propósito de ilustrar con las misma la exposición de la noticia. No obstante, hay determinados procesos en los que el interés informativo es mayor, pensemos en los juicios con jurado por delitos de homicidio, juicios contra la salud pública o de carácter económico en los que haya pluralidad de afectados, o juicios en los que intervienen personajes con proyección política. En estos casos los medios demandan una cobertura mucho mayor mediante la grabación de la totalidad o parte del desarrollo del juicio; para evitar los perjuicios de una múltiple y simultánea presencia de cámaras es frecuente la utilización del denominado sistema de «pool», mediante la autorización de la toma de imágenes a un solo fotógrafo o cámara de televisión, que después debe facilitar, íntegramente, dicho material a los demás medios interesados.

Una posibilidad muy interesante es la toma y posterior distribución de una señal institucional de audio y video por parte de la propia Administración de Justicia que se podría valer de las cámaras ya

${ }^{53}$ El artículo 6 del Reglamento se refiere a una resolución motivada, pero surge la duda sobre si dicha resolución es puramente jurisdiccional o gubernativa, y si en tal caso puede ser recurrida por los medios de comunicación y en qué forma.

54 Se trata del denominado «mudo», es el método que más fácilmente suelen aceptar los Tribunales puesto que la presencia de los medios audiovisuales se limita a unos pocos minutos, generalmente antes del comienzo del juicio. 
existentes en las salas de vistas ${ }^{55}$. Una variante consistiría en la grabación sin difusión simultánea de la señal y su posterior tratamiento para emplear técnicas que permitan distorsionar la imagen o la voz de determinados participantes en la vista de tal modo que quede impedida su identificación; otras posibilidades consisten en el seguimiento del juicio a través de un circuito cerrado de televisión o la autorización para tomar, únicamente, planos fijos.

En los últimos años se aprecia el intento de normalizar el acceso de las cámaras, evidenciada en la amplia cobertura que por parte de los medios han recibido determinados juicios especialmente significati$\operatorname{vos}^{56}$. Mención especial merece la cobertura audiovisual con máxima publicidad que, como criterio general, sigue la Audiencia Nacional desde hace varios años ${ }^{57}$. En este sentido destaca la cobertura que recibió el juicio que por los atentados del 11-S se celebró en la Audiencia Nacional durante el año 2005 ${ }^{58}$; el Presidente del Tribunal, en el ejercicio de su función de policía de estrados, tomó la decisión de permitir una máxima transparencia informativa para lo cual se acordó la distribución de la señal de video y audio a los medios de comunicación $^{59}$. La señal de audio y video de la totalidad del juicio estaba a

55 Recordemos como la actual LEC, en su artículo 147 establece la obligación de que las actuaciones orales en vistas y comparecencias se registrará en soportes aptos para la grabación y reproducción del sonido y de la imagen. La toma y difusión de una señal institucional de audio y video es empleada habitualmente por la Audiencia Nacional. Experiencias de estas características han sido adoptadas en diversos Tribunales Superiores de Justicia, un buen ejemplo lo constituye el juicio celebrado durante el mes de enero de 2007 en la Audiencia Provincial de Navarra, en el que se enjuiciaba el asesinato de dos jóvenes en la localidad de Valtierra, se facilitó una señal institucional de audio y video de tal modo que las televisiones y radios podían seguir y grabar el juicio en una sala especialmente habilitada para ello.

56 Como el seguido en Valencia contra un anestesista acusado del contagio de la Hepatitis C a 276 pacientes, este juicio comenzó en septiembre del año 2005, se celebró en una sala especial de la Audiencia Provincial en Valencia. Para la celebración del juicio se aprovechó la red tecnológica de la Ciudad de la Justicia y el sistema de grabación de juicios para realizar la transmisión de las vistas a la sala de prensa para facilitar el trabajo de los medios de comunicación.

57 La Audiencia Nacional ofrece una señal institucional de video en la sala ordinaria, mientras que en las salas blindadas, donde se celebran los juicios de terrorismo, se graban los juicios mediante la utilización del sistema de pool. GÓMEZ BERMÚDEZ, J. y BENI UZÁBAL, E.: Levantando el velo. Manual de Periodismos Judicial. Editorial Dossat, Madrid, 2006, pp. 203 y 204.

${ }_{58}$ El juicio se seguía contra veinticuatro acusados por su pertenencia al grupo terrorista Al Qaeda y su colaboración en los atentados contra las Torres Gemelas ocurrido en Nueva York el 11 de septiembre de 2001.

59 Para la celebración del Juicio se acondicionó un edificio existente en el antiguo Parque Ferial de Madrid situado en la Casa de Campo; en la sala de vistas se emplazaron tres minicámaras Sony, imperceptibles a simple vista, que se manejaban desde 
disposición de las televisiones, las cadenas podían "pinchar» la señal institucional del juicio a través de Televisión Española en la modalidad de pool, pagando los gastos a medias ${ }^{60}$. Este mismo tipo de cobertura se ha seguido en el juicio por los atentados ocurridos en Madrid el 11$M$ de 2004, celebrado en el mismo lugar durante el año $2007^{61}$.

No puede, sin embargo, obviarse el enorme costo que supone la implantación y utilización de una señal institucional de video mediante el uso de cámaras robotizadas que son controladas por un operador desde un control anexo, por lo que su uso quedará restringido, por el momento, al seguimiento de un limitado número de juicios que revistan una relevancia pública cualificada.

No obstante, dejando al margen la situación en la Audiencia Nacional, la consolidación de la nueva doctrina establecida por el Tribunal Constitucional requerirá del transcurso de un periodo de tiempo suficiente para desterrar las reticencias, prevenciones y reservas que, en un sector de la judicatura, despierta la presencia de los medios audiovisuales. Así, se puede advertir que en la práctica habitual de muchos Tribunales se siguen imponiendo determinadas restricciones que no siempre aparecen suficientemente motivadas; resoluciones respecto de las cuales, además, no está previsto mecanismo alguno de impugnación por parte de los medios audiovisuales que se ven afectados.

Esta situación ha sido puesta de manifiesta por GÓMEZ BERMÚDEZ y BENI UZÁBAL que se refieren a las múltiples trabas que los

un control de realización por personal técnico de la empresa Fujitsu. Por otro lado se habilitó una sala de prensa con cuatro pantallas de plasma de 42 » desde donde se podía seguir la celebración del juicio.

60 TVE llevaba la señal desde la Casa de Campo a Torre España y desde allí se distribuía a los interesados. Aquellas televisiones que no podían afrontar estos costes podían "pinchar» directamente la señal desde la propia sala de prensa mediante un grabador. Todas las notas sobre la celebración de este juicio se han obtenido de BERBELL, C: «Un caso de transparencia judicial», en Cuadernos de Periodistas, $n .{ }^{\circ}$ de julio de 2005. pp., 92 y ss.

${ }^{61}$ Las cadenas de televisión podían acceder a la señal institucional de video, grabada por cuatro pequeñas cámaras situadas en el interior de la sala, cuyas imágenes eran montadas por un realizador bajo la tutela del presidente del Tribunal. El mismo tenía la posibilidad de cortar la imagen en cualquier momento desde su propia mesa pulsando un botón. El juicio se retransmitió en directo tanto por televisión como a través de Internet. En las IV Jornadas de Comunicación y Justicia celebradas en Pamplona del 3 al 5 de octubre, los asistentes definieron la estrategia y desarrollo de la vista oral como "modélica», el lema que había presidido la celebración del juicio: «transparencia, toda; espectáculo, cero», contribuyó a dar una imagen de «cercanía y de servicio público» de la Justicia. 
Tribunales suelen imponer a la toma de imágenes, por lo que existe el peligro de que la situación siga anclada en la vieja doctrina del régimen de prohibición general con reserva de autorización. Estos autores denuncian la práctica de la mayoría de los Tribunales de decidir sobre el acceso de las cámaras en el momento en que se va a iniciar el acto del juicio oral, por lo que ante cualquier prohibición o limitación, los medios afectados no disponen de mecanismo alguno para recurrir de una forma efectiva dicha actuación puesto que el juicio comienza a desarrollarse a continuación ${ }^{62}$.

Desde el ámbito periodístico también se ha denunciado esta falta de aplicación de la doctrina recogida en las sentencias del Tribunal Constitucional ${ }^{63}$, advirtiendo que, en muchas ocasiones, los autos que establecen restricciones a la presencia de las cámaras se fundamentan únicamente en la oposición del propio acusado o en la voluntad contraria de los magistrados, fiscales o secretarios judiciales que intervienen en la vista oral. Es evidente que la oposición a la toma de imágenes por parte de alguno de los intervinientes en el acto del juicio oral puede motivar la adopción de determinadas limitaciones; pero el valor que debe conferirse a la voluntad contraria a la presencia de las cámaras varía mucho según la posición que se ocupe en el mismo.

Consideramos que no cabe limitar la toma de imágenes con base en la negativa de las autoridades y funcionarios que deben actuar en el proceso puesto que, en principio, no cabe admitir que los mismos puedan alegar el derecho a su propia imagen, puesto que resulta de aplicación lo establecido en el artículo 8.2.a) de la LO 1/1982, de 5 de

${ }^{62}$ GÓMEZ BERMÚDEZ, J. y BENI UZÁBAL, E.: Levantando el velo. Manual de periodismo judicial..., op.cit., pp. 267 a 273. Los autores indican como los jueces y magistrados encargados de ponderar los derechos en conflicto y de resolver en cada caso consideran que la Justicia es el bien supremo a defender, valor que se puede ver afectado por la presencia de las cámaras, por lo que de forma muy descriptiva advierten que ante la entidad de las restricciones impuestas, en muchas ocasiones que «sólo un plano del techo o del suelo podría salvarlos». También proponen, para posibilitar un eventual recurso ante el acuerdo por el que se deniega el acceso a las cámaras, la conveniencia de que se adopte el mismo al tiempo de dictar el auto de juicio oral.

${ }^{63}$ Esta crítica ha sido expuesta, entre otros, por el periodista del diario El País, MARTÍNEZ LÁZARO que señala: «...a dos años de la sentencia del Tribunal Constitucional sobre el acceso de los medios audiovisuales a las vistas de los juicios, la sentencia se sigue cumpliendo sin uniformidad, a criterio de cada tribunal, imponiendo restricciones no siempre suficientemente motivadas y a veces arbitrarias»; MARTÍNEZ LÁZARO, J.: "Dificultades de los medios en la obtención de la información judicial", en Justicia y medios de comunicación. Cuadernos de Derecho Judicial n. ${ }^{\circ} \mathrm{XVI}$. CGPJ, Madrid, 2007, pp. 237 y 238. 
mayo, de protección civil del derecho al Honor, a la Intimidad y a la Propia Imagen. Esto es, el derecho a la propia imagen no impide su captación y reproducción cuando se trate de personas que ejerzan un cargo público y su imagen se capte durante un acto público; ninguna duda existe acerca del carácter público de la actuación de jueces, fiscales y secretarios judiciales, ni del carácter público que tiene el acto del juicio oral ${ }^{64}$. No obstante, esta regla debe ceder en todos aquellos casos en los que concurran fundadas y evidentes razones de seguridad personal.

La negativa del acusado también debe ser ponderada cuidadosamente, si bien entendemos que la existencia de un interés público relevante determinará que la oposición del acusado a la toma de imágenes sea irrelevante en este sentido. Consideramos que son diversos los elementos que pueden valorarse por el órgano enjuiciador, en el momento de realizar la ponderación de los derechos en juego. En primer lugar, el derecho a la propia imagen debe ceder en todos aquellos casos en los que el acusado es una persona con relevancia pública, sobre todo, cuando los hechos delictivos enjuiciados están relacionados, precisamente, con una actividad de carácter público, como puede ser el caso del ejercicio de un cargo político ${ }^{65}$. En segundo lugar, consideramos que el derecho a la propia imagen no puede prevalecer en aquellos supuestos en los que la imagen del acusado ya sea suficientemente conocida. Por último, no puede dejarse de lado el hecho de que un determinado juicio, por la gravedad de los hechos que se enjuician y la repercusión que ha tenido en la opinión pública, pueda presentar un interés público especialmente relevante.

Distinta, por supuesto, es la situación de los que como peritos y testigos acuden al acto del juicio oral, a los que cabe otorgar una mayor protección, sobre todo cuando se trata de las víctimas del hecho delictivo. En el caso de los menores, el superior interés del menor determina que la ponderación entre derechos no deba ser la misma que cuando se trata de adultos, por lo que la libertad de información debe quedar relativizada; no es, por tanto, admisible la toma de imágenes de los menores que intervengan en un proceso penal sea cual fuera la posición que ocupen en el mismo.

${ }^{64}$ La Fiscalía General del Estado considera que el citado artículo es de aplicación a todos los funcionarios reseñados. Vid. Instrucción 3/2005, apartado VIII. En la misma se considera que los Abogados y Procuradores también deben estar sometidos a la citada regla puesto que son personas que están ejerciendo una profesión de proyección pública.

${ }^{65}$ En este sentido vid. Instrucción de la FGE 3/2005, apartado VIII. 
En cualquier caso consideramos que si por las razones que sean, suficientemente expuestas y motivadas en la resolución que se adopte, se considera que no es procedente tomar imágenes de determinados intervinientes en el acto del juicio oral, la alternativa no puede ser impedir de forma absoluta la captación de las mismas, pues es perfectamente admisible la adopción de medidas intermedias que posibiliten la conjugación del derecho a informar y el respeto a los derechos que las medidas de restricción tratan de proteger. Como hemos advertido anteriormente, y así se recoge en la doctrina del $\mathrm{TC}^{66}$, los tribunales deben contemplar la posibilidad de establecer una serie de medidas que, sin limitar totalmente la posibilidad de entrada de los medios audiovisuales, sean suficientes para la protección de los bienes jurídicos o derechos que pueden verse puestos en peligro.

Entendemos que resulta imprescindible que, respetando las facultades jurisdiccionales de cada juez, por parte del legislador se dicten unas normas que establezcan una mínima regulación de las diversas cuestiones que plantea el acceso de los medios, sobre todo los audiovisuales, a las salas de vistas.

Entre otras muchas: el procedimiento a seguir para resolver sobre las limitaciones o restricciones de acceso, el régimen de intervención del Ministerio Fiscal y el resto de partes del proceso, la cuestión de las acreditaciones, la reserva de espacios a los medios de comunicación, las modalidades de acceso, la posibilidad de obtener una imagen o señal institucional que después se facilite a los medios de comunicación, la transmisión en directo de los juicios, la existencia de canales destinados exclusivamente a tal fin, la posibilidad de que los medios de comunicación a los que, eventualmente, se les prohíba el acceso puedan interponer algún tipo de recurso ${ }^{67}$, así como las concretas funciones a desempeñar por los Gabinetes de Comunicación.

Unas normas de tal naturaleza dotarían de uniformidad a las decisiones que se adopten en esta materia, creando un marco jurídico

${ }^{66}$ SSTC 56 y 57/2004, fundamento jurídico $7 .^{\circ}$

${ }^{67}$ Esta resolución entendemos que reviste carácter gubernativo y, por tanto, debe ser susceptible de recurso ante la Sala de Gobierno del Tribunal respectivo, debe indudablemente estar motivada y dictarse en un momento procesal que no haga inútil la presentación de un eventual recurso. GÓMEZ BERMÚDEZ y BENI UZÁBAL consideran que el acuerdo que se adopte debe hacerse con antelación suficiente tanto por aplicación del principio de buena fe, por aplicación del principio de confianza de los ciudadanos en la Administración de Justicia y por aplicación del derecho a la tutela judicial efectiva; en op. cit., pp. 273 y 274. 
previsible y no discriminatorio, evitando prácticas y usos diferenciados que van en detrimento de la necesaria seguridad jurídica. Estas normas, en la medida que afectan al ejercicio de derechos fundamentales, tendrían su cabida mejor en la propia Ley Orgánica del Poder Judicial y no en una norma de carácter reglamentario sin perjuicio de su ulterior desarrollo.

\section{BIBLIOGRAFÍA}

CARRILLO LÓPEZ, M.: "Configuración general del derecho a comunicar y recibir información veraz: Especial referencia a las relaciones entre Poder Judicial y medios de comunicación" en Justicia y Medios de Comunicación. Cuadernos de Derecho Judicial. CGPJ, Madrid, 2007.

CATALA i BAS, A.H.: Libertad de expresión e información: la jurisprudencia del TEDH y su recepción por el Tribunal Constitucional. Revista General del Derecho, Valencia, 2001.

DEL VAL VELILLA, L.: «El tratamiento televisivo de las noticias criminales», en Justicia, información y opinión pública, Revista del Poder Judicial, n. ${ }^{\circ}$ especial XVII. CGPJ, Madrid, 1999.

ESCOBAR DE LA SERNA, L.: Derecho de la Información. Dykinson, Madrid, 2004.

GARCÍA PÉREZ, S.F.: «La televisión desde la sala del juicio en los procesos penales», en Revista del Poder Judicial, número especial XVII. CGPJ, Madrid, 1999.

GÓMEZ BERMÚDEZ, J. y BENI UZÁBAL, E.: Levantando el velo. Manual de periodismo judicial. Editorial Dossat, Madrid, 2006.

LÓPEZ ORTEGA, J.J.: «La dimensión constitucional del principio de la publicidad de la justicia" en Justicia, información y opinión pública, Revista del Poder Judicial, $n .{ }^{\circ}$ especial XVII. CGPJ, Madrid, 1999.

- «Información y Justicia», en Justicia y Medios de Comunicación, Cuadernos de Derecho Judicial n. ${ }^{\circ}$ XVI (2006), CGPJ, Madrid, 2007.

LUCAS MURILLO, P.L.: «La responsabilidad de los tribunales ante la opinión pública y ante los medios informativos", en Poder Judicial y medios de comunicación, Estudios de Derecho Judicial, $n .^{\circ} 39$. CGPJ, Madrid, 2001. 
NARVÁEZ RODRÍGUEZ, A.: «La Administración de Justicia y los medios de comunicación", en Estudios del Ministerio Fiscal, IV2002. Ministerio de Justicia, Madrid, 2002.

PERAL PARRADO, M.: "Configuración general del derecho a la libertad de comunicar y recibir información", en Justicia y medios de comunicación. Cuadernos de Derecho Judicial n. ${ }^{\circ} X V I$. CGPJ, Madrid, 2007.

REMÍREZ DE GANUZA, C.: «Información sobre Tribunales: perspectiva periodística sobre los procesos judiciales», en Estudios del Ministerio Fiscal, IV-2002. Ministerio de Justicia, Madrid, 2002.

ROXIN, C.: «El Proceso Penal y los medios de comunicación», en $R e$ vista del Poder Judicial, n. ${ }^{\circ}$ 55. CGPJ, Madrid, 1999.

VIEIRA, F.J.: «Análisis y consecuencias de la sentencia del Tribunal Constitucional sobre la presencia de los medios audiovisuales en los juicios», en VV.AA., Nuevos retos y perspectivas de investigación en la comunicación. Fundación General de la Universidad Complutense, Madrid, 2005. 